\title{
pH sensing and regulation in cancer
}

\section{Mehdi Damaghi, Jonathan W. Wojtkowiak and Robert J. Gillies*}

Department of Cancer Imaging and Metabolism, Moffitt Cancer Center and Research Institute, Tampa, FL, USA

\section{Edited by:}

Ebbe Boedtkjer, Aarhus University, Denmark

\section{Reviewed by:}

Christian Stock, University of

Muenster, Germany

Scott K. Parks, University of Nice,

France

\section{*Correspondence:}

Robert J. Gillies, Department of Cancer Imaging and Metabolism, Moffitt Cancer Center and Research Institute, 12902 Magnolia Drive,

Tampa, FL 33612, USA

e-mail: robert.gillies@moffitt.org
Cells maintain intracellular $\mathrm{pH}\left(\mathrm{pH}_{\mathrm{i}}\right)$ within a narrow range (7.1-7.2) by controlling membrane proton pumps and transporters whose activity is set by intra-cytoplasmic $\mathrm{pH}$ sensors. These sensors have the ability to recognize and induce cellular responses to maintain the $\mathrm{pH}_{\mathrm{i}}$, often at the expense of acidifying the extracellular $\mathrm{pH}$. In turn, extracellular acidification impacts cells via specific acid-sensing ion channels (ASICs) and proton-sensing G-protein coupled receptors (GPCRs). In this review, we will discuss some of the major players in proton sensing at the plasma membrane and their downstream consequences in cancer cells and how these $\mathrm{pH}$-mediated changes affect processes such as migration and metastasis. The complex mechanisms by which they transduce acid $\mathrm{pH}$ signals to the cytoplasm and nucleus are not well understood. However, there is evidence that expression of proton-sensing GPCRs such as GPR4, TDAG8, and OGR1 can regulate aspects of tumorigenesis and invasion, including cofilin and talin regulated actin (de-)polymerization. Major mechanisms for maintenance of $\mathrm{pH}_{\mathrm{i}}$ homeostasis include monocarboxylate, bicarbonate, and proton transporters. Notably, there is little evidence suggesting a link between their activities and those of the extracellular $\mathrm{H}^{+}$-sensors, suggesting a mechanistic disconnect between intra- and extracellular $\mathrm{pH}$. Understanding the mechanisms of $\mathrm{pH}$ sensing and regulation may lead to novel and informed therapeutic strategies that can target acidosis, a common physical hallmark of solid tumors.

Keywords: proton sensors, pH regulators, cancer microenvironment, buffer therapy, extracellular acidification, and intracellular $\mathrm{pH}$

\section{ACIDOSIS AND pH REGULATION IN CANCER CELLS}

The physical microenvironment of solid tumors is heterogeneous. A combination of poor vascular perfusion, regional hypoxia, and increased flux of carbons through fermentative glycolysis leads to extracellular acidosis in solid tumors; with extracellular $\mathrm{pH}\left(\mathrm{pH}_{\mathrm{e}}\right)$ values as low as 6.5 (Hashim et al., 2011). Notably, environmental acidification initially occurs early in cancers, during the avascular phase of carcinoma in situ, CIS (Barathova et al., 2008). There is reason to suspect that the most acidic CIS are more prone to progress to local invasion. With intraductal hyperplasia, IDH, cancer cells become increasingly distant from the basement membrane and underlying vasculature. These cells encounter an oxygen poor environment and, through a Pasteur effect, undergo a metabolic switch toward a more glycolytic phenotype (Gatenby and Gillies, 2004). Consequently, the proton $\left(\mathrm{H}^{+}\right)$concentration increases within the lumen due to diffusion limitations and increased production of acid from hypoxic-glycolytic cells, causing the interior of the lumen to become highly acidic. Later on in carcinogenesis, the glycolytic phenotype can become "hardwired" (i.e., the Warburg effect) and this leads to the continued generation of metabolic acids, even in well-oxygenated conditions (Figure 1). Adaptations to this highly acidic microenvironment are critical steps in transition from an avascular pre-invasive tumor to a malignant invasive carcinoma that has access to patent vasculature (Lee et al., 2008). If acidosis contributes to the development of invasive carcinoma, then an intervention that neutralizes $\mathrm{pH}_{\mathrm{e}}$ will either delay or inhibit this last step in carcinogenesis. We have shown, using
31P-MRS of 3-aminopropylphosphanate, that administration of oral buffers (200 mM sodium bicarbonate) significantly raises the $\mathrm{pH}_{\mathrm{e}}$ of xenograft tumors without altering $\mathrm{pH}_{\mathrm{i}}$ (Raghunand et al., 1999). More importantly, buffer therapy has the ability to reduce the formation of spontaneous and experimental MDA-MB-231 lung metastases (Robey et al., 2009) and suppress the formation of spontaneous prostate tumors in the TRAMP prostate GEMM (Ibrahim-Hashim et al., 2012).

The glycolytic byproducts, lactate and $\mathrm{H}^{+}$, challenge the mechanisms to maintain intracellular $\mathrm{pH}\left(\mathrm{pH}_{\mathrm{i}}\right)$ homeostasis. Intracellular acidification has been shown to be cytotoxic through induction of apoptosis (Gottlieb et al., 1996; Lagadic-Gossmann et al., 2004). To overcome low $\mathrm{pH}_{\mathrm{i}}$ due to elevated rates of glycolysis, cancer cells employ a large redundancy of mechanisms to remove acids in order to maintain physiological $\mathrm{pH}_{\mathrm{i}}$. In response to glycolytic acidosis, $\mathrm{pH}_{\mathrm{i}}$ can be be maintained via lactate and $\mathrm{H}^{+}$efflux by monocarboxylate transporters and Na-driven proton extrusion, respectively (Gillies, 2002; Gallagher et al., 2008). As a consequence, the $\mathrm{pH}$ of the extracellular space of tumors becomes acidic; forming a reversed $\mathrm{pH}$ gradient $\left(\mathrm{pH}_{\mathrm{e}}<\mathrm{pH}_{\mathrm{i}}\right)$ in comparison to normal physiological conditions $\left(\mathrm{pH}_{\mathrm{e}}>\mathrm{pH}_{\mathrm{i}}\right)$ (Figure 1) (Stubbs et al., 1994; Webb et al., 2011).

A reversed, acid-outside, $\mathrm{pH}$ gradient promotes cancer progression, via the relatively acidic $\mathrm{pH}_{\mathrm{e}}$ that induces migration and invasion (Bradley et al., 2011; Hanahan and Weinberg, 2011). Increased $\mathrm{pH}_{\mathrm{i}}$ by itself also has effects on cancer cell function such as increased proliferation (Moolenaar et al., 1986), promoting cell survival by limiting apoptosis, which is associated 

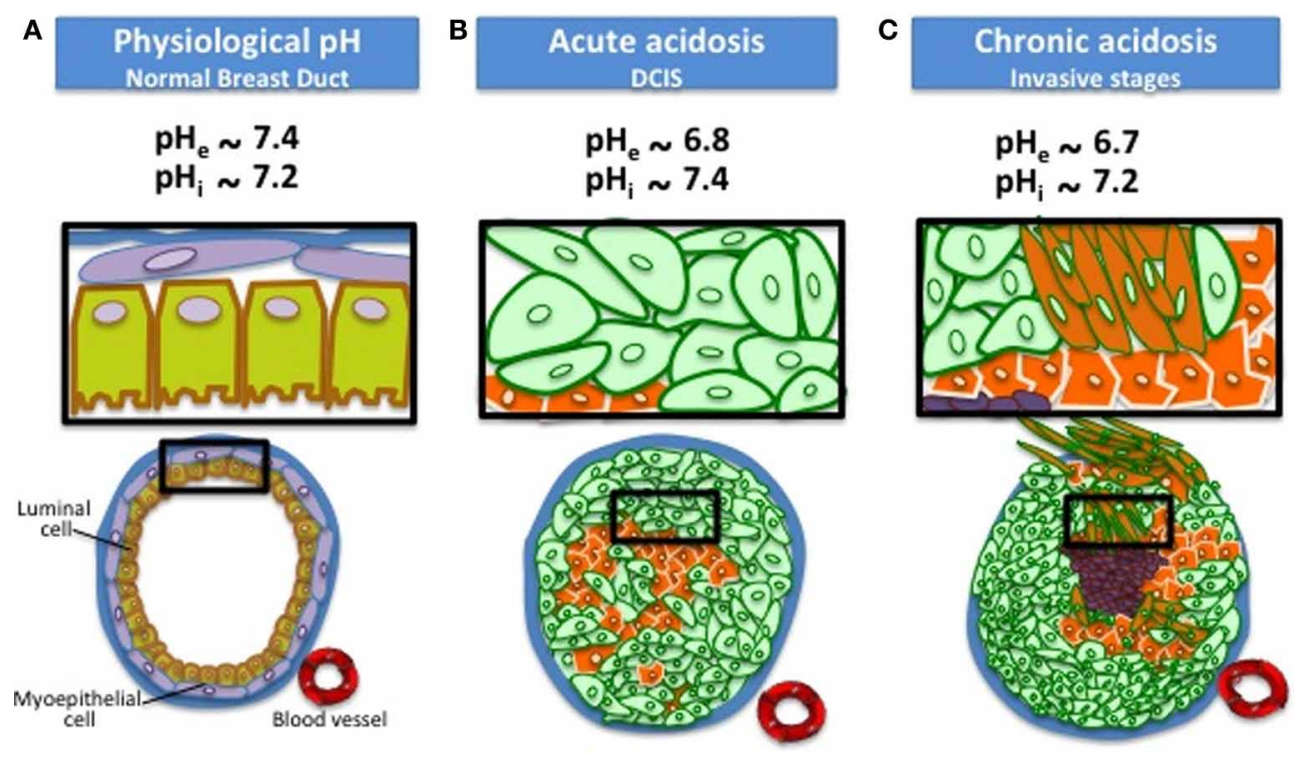

FIGURE 1 | Reversed extracellular and intracellular pH in cancer cells compared to normal cells. Cancer cells have a reversed $\mathrm{pH}$ gradient compared with normal differentiated cells that is cancer cells have a higher $\mathrm{pH}_{\mathrm{i}}$ and a lower $\mathrm{pH}_{\mathrm{e}}$ than normal cells in acute acidosis conditions. The $\mathrm{pH}_{\mathrm{e}}$ becomes even lower ( 6.7) in chronic acidosis. This disruption facilitates the adaptive behaviors of cancer cells such as cytoskeleton remodeling and directed migration, apoptosis evasion, extracellular matrix (ECM) remodeling, invasion, and metastasis. with intracellular acidification (Matsuyama and Reed, 2000), and selective advantages of growth-factor independent proliferation.

In order to survive the dynamic nature of $\mathrm{pH}$ in tumors, both cancerous and normal stromal cells require the ability to sense minute $\mathrm{pH}$ changes and respond appropriately to maintain $\mathrm{pH}_{\mathrm{i}}$ homeostasis. One mechanism by which $\mathrm{pH}$ sensing occurs is through post-translational protonation of amino acid side chains, in particular the imidazole side chain of histidine residues. Although under-represented in the human proteome with $\sim 2 \%$ frequency (Webb et al., 2011), histidines are found in critical regions of G-protein coupled receptors, GPCRs (OGR1 and GPR4), intracellular molecules involved in actin assembly (Talin and Cofilin), membrane proton pumps and acid-sensing ion channels, ASICs (Schonichen et al., 2013b). Protonation and de-protonation has been experimentally shown to change protein structure and thus, alter protein-protein binding affinity, change protein stability, modify protein function, and alter subcellular localization (Schonichen et al., 2013b). Evolutionarily, histidines must confer some selective advantage for cancers, as $15 \%$ of the 2000 identified somatic mutations in cancer involve histidine subsitutions, with Arg-to-His being the most frequent (Kan et al., 2010). The $\mathrm{pH}$ sensing role of histidines in cancer will be discussed further in this review.

\section{SECTION 1: THE INTRACELLULAR $\mathrm{pH}$}

Regulation of $\mathrm{pH}$ starts with changes in the expression or activity of several plasma membrane molecules such as pumps and transporters that facilitate $\mathrm{H}^{+}$efflux to maintain the alkaline $\mathrm{pH}_{\mathrm{i}}$ and the acidic $\mathrm{pH}_{\mathrm{e}}$ in tumor cells (Huber et al., 2010). These redundant mechanisms of tumor $\mathrm{pH}$ regulation include: Carbonic Anhydrases such as CA2, CA9, and CA12 (Barathova et al., 2008;
Supuran et al., 2010); V-ATPase (Hinton et al., 2009); $\mathrm{Na}^{+} / \mathrm{HCO}_{3}^{-}$ co-transporters (Pouyssegur and Mechta-Grigoriou, 2006); the $\mathrm{Na}^{+}$-driven $\mathrm{Cl}^{-} / \mathrm{HCO}_{3}^{-}$exchanger, SLC4A8 (Pouyssegur et al., 2006); the monocarboxylate transporters: MCT1, MCT2, MCT3, and MCT4 (Enerson and Drewes, 2003); $\mathrm{Na}^{+} / \mathrm{H}^{+}$exchanger 1, NHE1, which is also known as SLC9A1 (Amith and Fliegel, 2013); and the anion exchangers AE1 and AE2, also known as SLC4A1 and SLC4A2 (Barneaud-Rocca et al., 2011) (Figure 2).

\section{CARBONIC ANHYDRASES (CAs)}

The CA family of proteins are metalloenzymes that catalyze the conversion of carbon dioxide generated in high amounts as the final product of oxidative phosphorylation and water to bicarbonate and protons. A primary function of CAs is to maintain the intra- and extracellular acid-base balance. CAIX and CAXII are transmembrane CAs that have been identified to play roles in tumor progression and metastasis (Tafreshi et al., 2012; Ilie et al., 2013). It has recently been shown that CAIX in colon cancer and glioblastoma promotes tumor growth and necrosis (McIntyre et al., 2012). As a transcriptional target of HIF1 $\alpha$, CAIX expression is upregulated in hypoxic regions of tumors including breast cancer (Tafreshi et al., 2012). CAXII is also overexpressed in tumors and is associated with cancer progression. Although CAXII and CAIX can be expressed in the same cells, their intratumoral distributions are often different with more global and more regional distributions, respectively (Tafreshi et al., 2012). Intracellular CAs (e.g., CAII) will dehydrate metabolically produced bicarbonate into aqueous $\mathrm{CO}_{2}$ in a reaction consuming a proton. By mass action, the $\mathrm{CO}_{2}$ is exported across the bilayer or through aquaporins, where it is re-hydrated by CAIX or CAXII to re-produce $\mathrm{HCO}_{3}^{-}$in a reaction producing an extracellular 


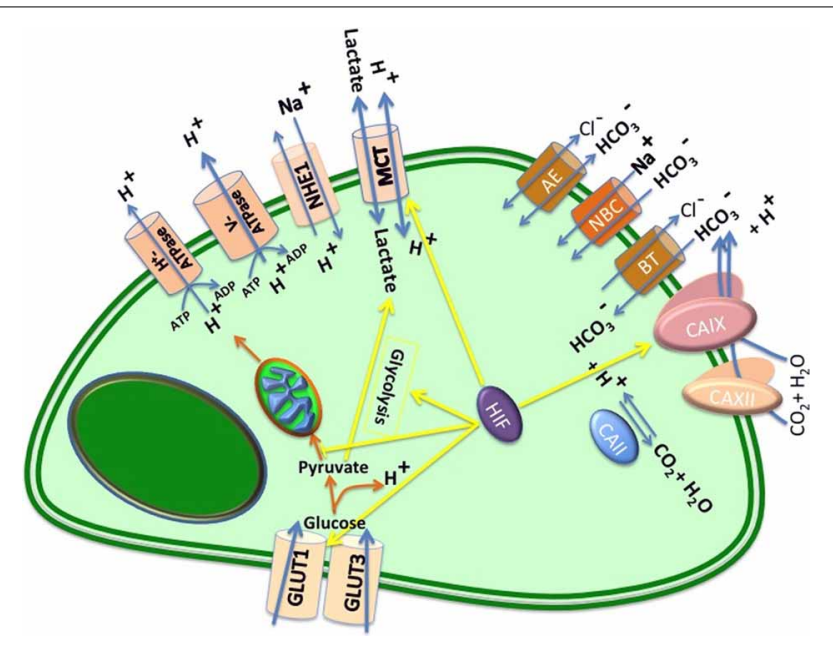

FIGURE 2 | Major pH regulators in a cancer cell. After glucose uptake by specific transporters (GLUT1 and GLUT3), glucose is converted to pyruvate, generating 2 ATP per glucose and proton. Based on Pasteur effect, in the presence of oxygen, pyruvate is oxidized to $\mathrm{HCO}_{3}^{-}$, generating 36 additional ATP per glucose; in the absence of oxygen pyruvate is reduced to lactate, which is exported to extracellular space. However, as Warburg proposed glycolysis is potent in cancer cells. Notably both processes produce protons $\left(\mathrm{H}^{+}\right)$, which cause acidification of the extracellular space. This figure represents main proteins that regulate intracellular and extracellular $\mathrm{pH}$ in tumors, including: monocarboxylate transporters (MCTs), which transport lactic acid and other monocarboxylates formed by the glycolytic degradation of glucose; the plasma membrane proton pump vacuolar ATPase (V-ATPase); $\mathrm{Na}^{+} / \mathrm{H}^{+}$exchangers (NHEs); anion exchangers (AEs); carbonic anhydrases (CAII, CAIX, and CA XII); $\mathrm{Na}^{+} / \mathrm{HCO}_{3}^{-}$co-transporters (NBCs), and $\mathrm{HCO}_{3}^{-}$-transporters (BTs).

proton. The $\mathrm{HCO}_{3}^{-}$can then diffuse out of the tumor, or re-enter the cell via bicarbonate transporters or anion exchangers to maintain a more alkaline $\mathrm{pH}_{\mathrm{i}}$ (Xie et al., 2009; Swietach et al., 2010). CAIX is an important facilitator of acid diffusion that its importance in regulating tumor $\mathrm{pH}$ has made it a potential target for designing new therapeutics against cancer (Swietach et al., 2010).

\section{$\mathrm{HCO}_{3}^{-}$TRANSPORTERS}

These proteins are mainly clustered into three classes: electroneutral $\mathrm{Cl}^{-} / \mathrm{HCO}_{3}^{-}$exchangers of the SLC4 family; the NBC family of $\mathrm{Na}^{+} / \mathrm{HCO}_{3}^{-}$co-transporters; and anion transporters of the SLC26 family. Additionally, $\mathrm{HCO}_{3}^{-}$transport via aquaporins has been reported (Cooper et al., 2002). These transporters facilitate the movement of $\mathrm{HCO}_{3}^{-}$ions across plasma membranes to either acidify or alkalinize the $\mathrm{pH}_{\mathrm{i}}$ (Vilas et al., 2009). It has been shown via functional assays that the $\mathrm{Na}^{+} / \mathrm{HCO}_{3}^{-} \mathrm{Co}-$ transporter (NBCn1) is the predominant mechanism for acid extrusion in breast carcinoma tissue when $\mathrm{pH}_{\mathrm{i}}$ levels are greater than 6.6 (Boedtkjer et al., 2013). In fact, inhibition of NBCn1, in NHE1 expressing cells, resulted in $\mathrm{pH}_{\mathrm{i}}$ acidification suggesting that NBCn1 should garner further attention as a therapeutic target (Boedtkjer and Aalkjaer, 2012; Boedtkjer et al., 2012).

\section{NHE1}

NHE1 is the most common isoform of the $\mathrm{Na}^{+} / \mathrm{H}^{+}$exchanger (NHE) family that is present in all mammalian cells. The NHEs
(NHE1-NHE7) are amongst the most active transporters in $\mathrm{pH}_{\mathrm{i}}$ homeostasis and use the powerful sodium electrochemical gradient to extrude $\mathrm{H}^{+}$if the cytosolic $\mathrm{pH}$ becomes too acidic. Notably, there is a $\mathrm{pH}$ sensing site on the internal surface of the NHE that, if protonated, activates transport. This "set-point" can be altered by growth factor (e.g., EGF) activation. In cancer cells with their high metabolic acid load, NHE1 hyperactively extrudes protons into the extracellular space making it acidic. Particularly in breast cancer, it has been suggested that upregulation of NHE1 activity is a main factor for increased invasion and metastasis (Gatenby and Gillies, 2008; Busco et al., 2010; Amith and Fliegel, 2013). For example, it has been shown that CD44, which is a cell surface glycoprotein, is localized at the invadopodia of an invasive breast cancer cell line, MDA-MB-231 cells. CD44 stimulates NHE1 activity leading to invasion through the RhoA effector ROCK1 (Bourguignon et al., 2004). It has also been shown that RAC1 and the RhoA-ROCK-PI3K pathway are involved in CD44-induced cell invasion (Bourguignon et al., 2001). In cervical cancer, it has been shown that NHE1 up-regulation by EGF is important for cervical cancer cell invasiveness (Chiang et al., 2008). Hence, it appears that signaling molecules can activate NHE1 leading to a reversed $\mathrm{pH}$ gradient. Treating MDA-MB-231 cells with an NHE inhibitor (cariporide) suppressed the invasive capability of this highly metastatic breast cancer cell line (Lin et al., 2011a,b).

\section{V-ATPase}

Vacuolar ATPases pump protons out of the cytoplasm and into intracellular vesicles, such as lysosomes in an ATP dependent process (Horova et al., 2013) and these events are also altered in cancer (Perez-Sayans et al., 2009a,b). Importantly, the activity of these pumps is tightly coupled to endosome trafficking, suggesting that they need not be resident at the plasma membrane to exert their pH regulatory effects (Martinez-Zaguilan et al., 1999, 2013). Indeed, Glunde et al. (2003, 2005) and Cardelli (Steffan et al., 2009) have both shown that low $\mathrm{pH}$ induces the turnover of endosomal-lysosomal compartments with the extracellular space, which could be an indirect mechanism for V-ATPase mediated extrusion of $\mathrm{H}^{+}$from the cytosol. Saw et al. recently showed that high-metastatic B16-F10 melanoma cells overexpress the a3 isoform V-ATPase compared to the low-metastatic B16 parental cells and V-ATPase inhibitors reduced bone metastasis (Saw et al., 2011).

\section{MONOCARBOXYLATE TRANSPORTER (MCTs)}

MCTs transport mono-carboxylic acids (such as lactate, pyruvate, and ketone bodies) into and out of cells across plasma and mitochondrial membranes. The MCT family is composed of 14 members with similar topology and can be found expressed in a wide range of tissues. Only 4 isoforms (MCT1-MCT4) have been functionally characterized as proton-linked monocarboxylate transporters (Morris and Felmlee, 2008; Halestrap, 2012; Halestrap and Wilson, 2012). This is critical as MCTs (MCT1 and MCT4) are routinely overexpressed in tumors primarily regulating the efflux of lactate and protons as byproducts of glycolysis from intracellular to extracellular space in order to maintain physiological $\mathrm{pH}_{\mathrm{i}}$ thus, contributing to extracellular acidosis. High expression levels of these transporters have been linked to 
poor prognosis and disease progression in colorectal, ovarian, gastric, and breast carcinomas (Pinheiro et al., 2009a,b, 2010; Chen et al., 2010).

So far, we have focused on tumor hypoxia and efflux mechanisms by which cancer cells regulate $\mathrm{pH}_{\mathrm{i}}$ on account of increased glycolysis. One mechanism discussed was the outward flux of lactic acid by MCT1/4. We must appreciate, however, that it not uncommon to observe well oxygenated and nutrient rich tissue coexisting with hypoxic and carbon poor tissue (Gatenby et al., 2013). Although these regions are metabolically distinct, it is hypothesized that carbon symbiosis occurs between glycolytic and oxidative compartments to promote tumor growth wherein hypoxic tissue mostly consumes glucose and oxygen rich tissue consumes the glycolytic byproduct, lactate (Nakajima and Van Houten, 2013). Sonveaux et al. have proposed that this transpires through specific intratumoral MCT1 expression patterns that are environmentally regulated (Sonveaux et al., 2008). Using human cervical and colon xenograft tumor models, MCT1 expression was highest in well-oxygenated tissue (CD31 positive) with little to no detectable expression in hypoxic (Pimonidazole positive) regions. The authors show that oxygenated tissue promotes the inward flux of lactate via MCT1 to fuel the TCA cycle and that in vivo inhibition of MCT1 with $\alpha$-cyano-4hydroxycinnamate limited tumor growth. Sonveaux hypothesized that the anti-tumor effect was a result of a metabolic switch from lactate-fueled respiration to glycolysis in oxygenated tissue further reducing the carbon source for hypoxic tissue (Sonveaux et al., 2008).

Similar observations were made by Koukourakis et al. in colorectal adenocarcinoma (Koukourakis et al., 2006). Using patient tissue, tumor, and stromal compartments were histologically and thus, metabolically distinguishable based on MCT and glucose transporter expression patterns. Colorectal adenocarcinoma was shown to express high glucose uptake (GLUT1) and lactate efflux (MCT1) proteins in respect to tumor associated stromal cells that expressed low glucose uptake and high lactate influx (MCT1 and MCT2) proteins driving lactate oxidation (Koukourakis et al., 2006). Similar cancer-stromal cell metabolic collaboration has also been proposed by Lisanti's group, who has observed MCT1 in tumors, and MCT4 in stroma, prompting them to characterize this as a "reverse Warburg Effect" (Witkiewicz et al., 2012). These examples highlight alternative roles for MCTs in addition to regulating $\mathrm{pH}_{\mathrm{i}}$ homeostasis and that inhibition of MCTs may disrupt tumor metabolism homeostasis providing therapeutic benefit.

\section{pH-SENSING PROTEINS THAT REGULATE ACTIN ASSEMBLY PLAY ROLE IN CANCER CELL MIGRATION}

Although the effects of $\mathrm{pH}$ on intracellular processes are ubiquitous, one of the major $\mathrm{pH}$-sensitive systems in the cells is the actin cytoskeleton. The assembly of globular (G-actin) to filamentous (F-actin) and higher structures as well as the reverse process of filament disassembly play different roles in cancer cell processes and behaviors such as vesicle trafficking, contraction, migration, invasion, and metastasis. De novo actin assembly in mammalian cells requires $\mathrm{pH}_{\mathrm{i}}>7.2$ (Webb et al., 2011) and changes (of 0.3-0.4 units) in $\mathrm{pH}_{\mathrm{i}}$ induce dramatic differences in actin filament assemblies and architectures. These observations suggest that disruption of $\mathrm{pH}_{\mathrm{i}}$ in either direction can negatively impact the mobility of cancer cells and eventually affect metastasis (Hansen and Kwiatkowski, 2013).

\section{ADF/COFILIN}

Polymerizing actin filaments, which are essential for migratory cells, requires the activity of the actin-severing protein, cofilin (Sidani et al., 2007). The actin depolymerizing factor (ADF)/cofilin family, including ADF, non-muscle cofilin-1 and muscle cofilin-2, are $\mathrm{pH}$ sensors that sever and nucleate actin filaments (Bravo-Cordero et al., 2013). In migrating cells, cofilin increases filament disassembly at one end of actin networks and generates free ends for nucleation and assembly at the plasma membrane (Bernstein and Bamburg, 2010). The severing activity of cofilin requires (de)phosphorylation of an $\mathrm{N}$-terminal serine residue and (de-) protonation of a C-terminal histidine residue. Overactivity of cofilin requires both the dephosphorylation of the serine and the deprotonation of histidine to occur. Although cofilin is not directly $\mathrm{pH}$ regulated, its binding to Phosphatidylinositol (Lope-Piedrafita et al., 2008) in the plasma membrane is $\mathrm{pH}$-dependent and regulates its activity. Dissociation from membrane PI at more alkaline $\mathrm{pH}_{\mathrm{i}}$ increases cofilin activity (Frantz et al., 2008).

$\mathrm{ADF}$ is extremely $\mathrm{pH}$ sensitive and its regulation occurs through a $\mathrm{pH}$-dependent salt-bridge at the F site between His133 and Asp98 of $\beta$-strand4. The salt-bridge is stable at slightly acidic conditions but broke at alkaline $\mathrm{pH}$, leading to partial unfolding of the F site and presumably increases actin-binding activity of ADF. Cofilin and ADF have differential $\mathrm{pH}$ sensitivity because they bind to actin in different ways (Schonichen et al., 2013b). Cofilin binding to cortactin in invadopodia (i.e., invasive plasmamembrane protrusions of cancer cells) sequesters inactive cofilin at the distal membrane of invadopodia and its binding affinity decreases as $\mathrm{pH}_{\mathrm{i}}$ increases (Magalhaes et al., 2011).

\section{TALIN}

Dynamic remodeling of actin filaments at focal adhesion sites is also $\mathrm{pH}_{\mathrm{i}}$ sensitive. This regulation is critical at the leading edge of migrating cells where increased $\mathrm{pH}_{\mathrm{i}}$ is needed (Stock and Schwab, 2009). It has been shown that $\mathrm{pH}_{\mathrm{i}}$ is higher at the leading edge of migrating cells and it is actually highest at the focal adhesions (Martin et al., 2011; Ludwig et al., 2013). The effect of $\mathrm{pH}_{\mathrm{i}}$ on focal adhesion is mediated partly by talin binding to F-actin, which binds actin filaments to focal adhesions. The N-terminal domain of talin that binds $\beta$-subunits of integrin receptors at the cytosolic side contains a $\mathrm{pH}$-insensitive F-actin-binding site (Critchley, 2009). On the other hand, the C-terminal module that also binds F-actin is pH dependent (Critchley, 2009). So, talin is a $\mathrm{pH}$-sensor whose binding to actin filaments decreases at a $\mathrm{pH}>7.2$, permitting faster focal adhesion turnover and increased migration (Srivastava et al., 2008). Protonation of amino acids in a $\mathrm{pH}$-sensor region causes conformational changes at distant actin-binding sites and allosterically regulates the actin-binding domain of talin (Srivastava et al., 2008; Critchley, 2009).

\section{GUANINE NUCLEOTIDE EXCHANGE FACTORS}

Some guanine nucleotide exchange factors (GEFs) contain $\mathrm{PH}$ (plextrin-homology) domains that show binding specificity to 
membrane phosphoinositides. One example is Dbs, a Dbl family Rho GEF that activates the Rho GTPase Cdc42 at the leading edge of migrating cells that leads to a polarized movement. Dbs contains a $\mathrm{PH}$ domain that binds to $\mathrm{PIP}_{2}$ with higher affinity at lower pH (Frantz et al., 2007). However, there are some other Dbl family Rho GEFs, such as intersectin, that contain a similar $\mathrm{PH}$ domain but with $\mathrm{pH}$-independent binding to $\mathrm{PIP}_{2}$. Most of Dbs but not all (such as intersectin) have a histidine (His843) at the $\mathrm{PIP}_{2}$-binding site of the $\mathrm{pH}$-sensitive domain (Frantz et al., 2007), similar to $\mathrm{pH}$-dependent binding of cofilin to $\mathrm{PIP}_{2}$.

Arf GTPases are localized at acidic endosomes and regulate endosomal trafficking and actin dynamics (Donaldson and Jackson, 2011). As an example, the pH domain of Grp1, a GEF for Arf GTPases, has $\mathrm{pH}$-dependent binding to phosphoinositides. In contrast to Dbs, Grp1 binds $\mathrm{PIP}_{3}$ instead of $\mathrm{PIP}_{2}$ at endosomal membranes, with a higher binding affinity at lower pH (He et al., 2008, 2011). Grpl's increased binding affinity is because of protonation of His355 located in the loop between $\beta 6$ and $\beta 7$ that interacts with the phosphate group 4 of inositol 1,3,4,5-tetrakisphosphate ( $\left.\mathrm{IP}_{4}\right)$ (Schonichen et al., 2013b).

It has been shown recently that phosphoinositide-binding domains are common in physiological $\mathrm{pH}$ sensing proteins such as Fablp, YOTB, Vaclp, and EEA1 (Lee et al., 2005), ENTH and ANTH. They all show increased phosphoinositide binding affinities at $\mathrm{pH}$ values below neutral $\sim 7.2$. A common feature of these domains is that they all contain at least one histidine for stereospecific phosphoinositide recognition. Although not experimentally shown yet, proteins containing these domains most probably have membrane localization and $\mathrm{pH}$ dependent activity and, if associated with the actin cytoskeleton, could regulate the actin filament dynamics at focal adhesions (Schonichen et al., 2013a,b). Understanding the significance of pH-dependent histidine switches for phosphoinositide can help to understand the role of $\mathrm{pH}$-regulated metastasis.

\section{SECTION 2. THE EXTRACELLULAR pH}

A consequence of $\mathrm{pH}$ homeostasis in the face of a high metabolic acid load is the transport of $\mathrm{H}^{+}$into the interstitial space. In tumors that are metabolically active, estimates of the interstitial space (Kep) from dynamic contrast enhanced (DCE) MRI, range from 6 to $12 \%$. Hence there is a 10 -fold greater acid load on the extracellular environment compared to intracellular, and this is generally relieved via diffusive transport of mobile buffers from the source, i.e., cells, to the sink, i.e., the vasculature (Schornack and Gillies, 2003). If these diffusion path lengths become long, e.g., greater than 50 microns, then the $\mathrm{pH}_{\mathrm{e}}$ becomes profoundly acidic. Such conditions are not only encountered in cancer, but in other pathological states, such as ischemia, or following trauma, and mammalian cells have evolved (or retained) sophisticated mechanisms to sense their environmental $\mathrm{pH}$ and adjust their behaviors accordingly.

\section{pH SENSORS IN PLASMA MEMBRANE}

Plasma membrane $\mathrm{pH}$ sensors in cells are categorized mainly as G-protein coupled receptors (GPCRs) and non-GPCR sensors. Proton-sensing GPCR expression varies by cell type. This subfamily of proton-sensing GPCRs includes GPR4, OGR1 (GPR68),
TDAG8 (GPR65), and G2A (GPR132), which have also been identified as receptors for lysolipids; sphingosylphosphorylcholine (SPC), lysophosphatidylcholine (LPC), and psychosine (galactosylsphingosine) (Ludwig et al., 2003). OGR1 is coupled with the $\mathrm{PLC} / \mathrm{Ca}^{2+}$ signaling pathway through $\mathrm{Gq} / 11$ proteins. On the other hand, GPR4 and TDAG8 are coupled with the cAMP signaling pathways via Gs. It has recently been observed that activation of TDAG8 with acid $\mathrm{pH}$ induces down regulation of c-myc in lymphoma cells (Li et al., 2013). Discovery of the proton-sensing ability of transient receptor potential V1 (TRPV1), a calciumchannel also known as the capsaicin receptor and the vanilloid receptor 1, was a breakthrough in the field of proton-sensing mechanisms, because it showed that non-GPCR proteins can also sense $\mathrm{pH}$ (Tomura et al., 2010). Another family of non-GPCR sensors is the acid-sensitive ion channels (ASICs), which include 7 proteins from 4 genes. It has been shown that ASIC1 and ASIC2 are expressed in the central nervous system and are important in pain processing (Wemmie et al., 2013). Understanding $\mathrm{pH}$ sensors will provide insight into the molecular basis of $\mathrm{pH}$-dependent phenomena that may help us to understand cancer cell behavior and eventually identify new diagnostics and therapeutics.

\section{OGR1}

Ovarian cancer G protein-coupled receptor 1 (OGR1), previously described as sphingosylphosphorylcholine receptor, is a proton sensing receptor that stimulates inositol phosphate formation. It is inactive at $\mathrm{pH}_{\mathrm{e}} \sim 7.8$ and fully activated at $\mathrm{pH}_{\mathrm{e}} \sim 6.8$ (Ludwig et al., 2003). Using a computational model, Ludwig et al demonstrated that the ability of OGR1 to sense $\mathrm{pH}$ resides within histidines located in the extracellular loops. They proposed that acidic $\mathrm{pH}$ destabilizes the hydrogen bonds of these histidines and switches the receptor to its active conformation. They also predicted five histidines (H17, H20, H84, H169, and $\mathrm{H} 269$ ) are key players and demonstrated that substituting each histidine with phenylalanine reduces the proton-sensing ability of OGR1 (Ludwig et al., 2003)

It has recently been shown that OGR1 deficiency $\left(O G R 1^{-/-}\right)$ in Transgenic Adenocarcinoma of the Mouse Prostate (TRAMP) model reduced tumor formation. The same group also showed similar results in murine melanoma cell xenografts in OGR1 $1^{-/-}$mice (Yan et al., 2012a,b). OGR1 expression is lower in human metastatic compared with primary prostate cancer tissue. In light of this observation, OGR1 has been characterized as a new metastasis suppressor gene in prostate cancer cells (Singh et al., 2007). This observation also extends to breast, where Li et al recently showed that OGR1 inhibits cell migration through a Ga12/13 -Rho-Rac1 signaling pathway in MCF7 breast cells (Li et al., 2013). These results suggest that OGR1 may act as a tumor and metastasis suppressor. However, the role of $\mathrm{pH}$ and protonactivated signaling in this protein and their relationship to this type of anti-tumor behavior needs to be investigated further.

Interestingly, OGR1 was also shown to be overexpressed in human medulloblastoma, a cancer of neuronal precursor cells. Activation of OGR1 in human medulloblastoma cell line triggers activation of the ERK signaling pathway through protonmediated $\mathrm{Ca}^{2+}$ release in the cytoplasm (Huang et al., 2008). This implies how extracellular acidification can promote cell 
survival in medulloblastoma. This important finding demonstrates a tumor promoting mechanism, different than the antitumor mechanism previously described in prostate cancer and melanoma. Additionally, they demonstrated that only proliferating cells have the ability to translate an acidic $\mathrm{pH}_{\mathrm{e}}$ into gene transcription, suggesting that the acidic microenvironment provides a survival advantage to proliferating cancer cells over nontransformed cells (Glitsch, 2011). In contrast, Yuan et al. have also recently shown that OGR1-mediated $\left[\mathrm{Ca}^{2+}\right]$ elevation induced apoptosis by activation of calcium-sensitive proteases and their downstream signaling molecules such as Bid, Bax, and caspase-3 in rat endplate chondrocytes (Yuan et al., 2013). Taken together, all these observations imply that transduction of the acid-sensing signal is highly context-dependent, leads to various phenotypes, and depends on the cell-specific genetic history and lineage.

\section{GPR4}

G-protein coupled receptor 4 (GPR4), a close relative of OGR1, also responds to $\mathrm{pH}$ changes, but elicits cyclic AMP formation and accumulation. GPR4 plays its $\mathrm{pH}$-sensing role through the $\mathrm{G}_{12 / 13}$-protein/Rho, the $\mathrm{G}_{\mathrm{q}} / \mathrm{PLC}$, and the $\mathrm{G}_{\mathrm{s}}$-protein/cAMP signaling pathways (Liu et al., 2010). Acid-induced GPR4 activates RhoA, stimulating the formation of actin stress fibers (Castellone et al., 2011). GPR4 is overexpressed in breast, ovarian, colon, liver, and kidney tumors at the mRNA level (Sin et al., 2004).

Osteosarcoma cells and primary human osteoblast precursors exhibit strong $\mathrm{pH}$-dependent inositol phosphate formation and constitutively express GPR4 at their membranes. Tumor growth in GPR4 $4^{-/-}$mice is abrogated, because of reduced angiogenesis, suggesting that acidic $\mathrm{pH}$-stimulated GPR4 may regulate endothelial cell growth (Wyder et al., 2011). Some GPR4 inhibitors are under development as antiangiogenesis therapeutics (PCT/EP07/63899). Buffer therapy, described above, might also lead to deprotonation and hence, deactivation of GPR4. Combination therapy using buffer or GPR4 inhibitors also might be considered as a possible therapy against primary and metastatic tumors.

\section{T-CELL DEATH-ASSOCIATED GENE 8 (TDAG8)}

TDAG8 is a $\mathrm{pH}_{\mathrm{e}}$-sensing GPCR that is overexpressed in different tumor types and cancer cell lines that also might play role in immune response of cancer cells (Ishii et al., 2005). TDAG8, also known as GPR65, was originally identified as an orphan GPCR in apoptotic thymocytes. It was later demonstrated to function as a $\mathrm{pH}_{\mathrm{e}}$ sensor that responds to extracellular acidification through $\mathrm{G}_{\mathrm{s}}$, thus, increasing cAMP (Radu et al., 2005). TDAG8 is overexpressed in kidney, colon and ovarian tumors (Sin et al., 2004). TDAG8 can also mediate acid-stimulated cancer bone pain through PKA signaling (Hang et al., 2012). Overexpressed TDAG8 at the cell membrane protects tumor cells against extracellular acidosis and can accelerate tumor development and shRNA knockdown of endogenous TDAG8 attenuates cancer cell survival in acidic media (Ihara et al., 2010). A mechanism for TDAG8 in cancer cells in acidic environment has been proposed wherein cell growth is related to TDAG8-mediated PKA and ERK activation (Figure 3). Overexpression of TDAG8 in NIH3T3 induces different types of oncogenic phenotypes such as rapid proliferation,

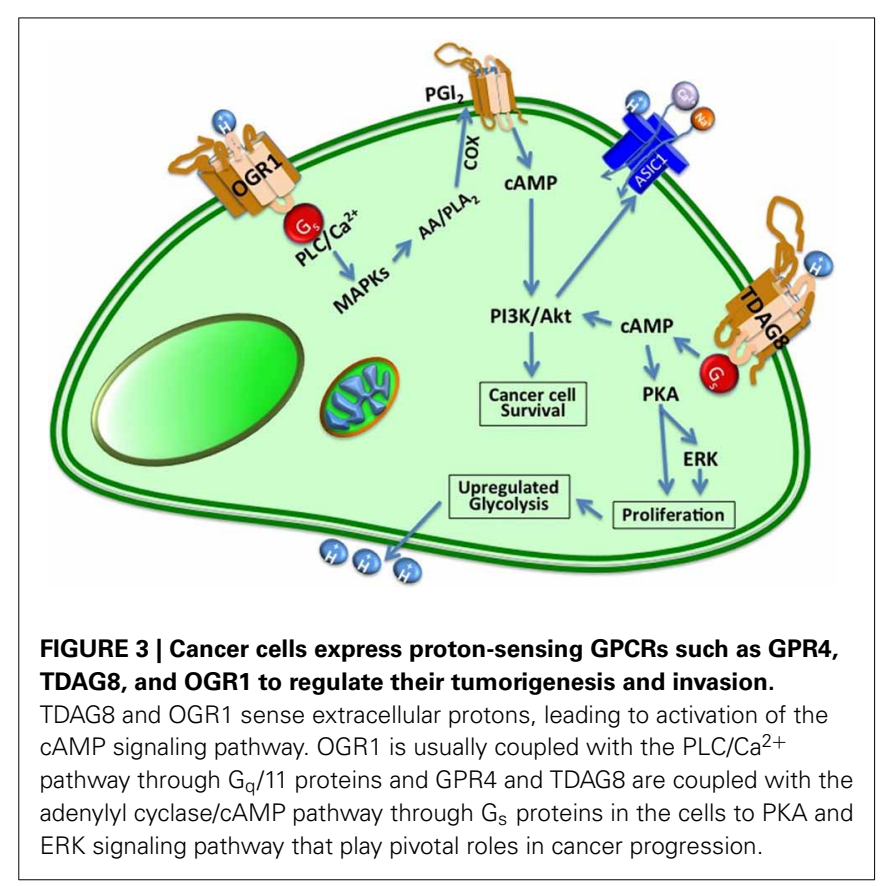

refractile cell shape, foci formation and tolerance to low serumconditioned media (Sin et al., 2004). Acid-activated TDAG8 can also stimulate RhoA, actin rearrangement, and stress fiber formation (Ishii et al., 2005).

\section{ACID-SENSITIVE ION CHANNELS (ASICs)}

ASICs are voltage-independent ion channels that are mainly expressed in peripheral sensory and central nervous system neurons. They are acid responsive and permeable to cations. They are also modulated by alkalosis and $\mathrm{pH}_{\mathrm{i}}$ and might play a role of mechanosensation in neurons (Wemmie et al., 2013). These proton-gated cation-selective channels are mostly permeable to $\mathrm{Na}^{+}$ions and belong to the degenerin/epithelial $\mathrm{Na}^{+}$channel (DEG/ENaC) superfamily (Jasti et al., 2007). There are seven subunits of ASICs encoded by four different genes: ASIC1a, ASIC1b1, ASIC1b2, ASIC 2a, ASIC 2b, ASIC 3, and ASIC 4, amongst them $1 \mathrm{a}, 2 \mathrm{a}, 2 \mathrm{~b}$, and 3 subunits are present in CNS neurons. The lowresolution crystal structure of the chicken ASIC1a at normal and low $\mathrm{pH}$ was determined in 2007 and illustrated that functional ASICs are trimeric assemblies (Jasti et al., 2007) (Figure 3). Each ASIC subunit consists of two transmembrane domains (TM1 and TM2) connected with a large extracellular loop that is cysteine rich. ASIC1a and heteromeric ASIC1a/2b channels are permeable to $\mathrm{Ca}^{2+}$ and can lead to an accumulation of intracellular $\mathrm{Ca}^{2+}$ inside neurons (Sherwood and Askwith, 2008). However, it's been shown that acidosis induced $\mathrm{Ca}^{2+}$ accumulation is not only due to the activation of ASIC1a and ASIC1a/2 channels but also could be due to activity of voltage-gated $\mathrm{Ca}^{2+}$ channels and/or release of $\mathrm{Ca}^{2+}$ from intracellular pools such as sarcoplasmic membranes in cancer cells (Leanza et al., 2013).

ASICs have different roles in peripheral neurons and CNS. In the periphery, it is postulated that ASICs are involved in nociception and mechano-sensation, (Sherwood et al., 2012); and in the CNS, different ASICs play different roles; as ASICla is 
involved in synaptic plasticity, learning/memory and fear conditioning; and ASIC2a is required for the maintenance of retinal integrity and survival of neurons in global ischemia. It has also been described that activation of $\mathrm{Ca}^{2+}$-permeable ASICla and ASIC1a/2b proteins are involved in acidosis-mediated neuronal degeneration (Pignataro et al., 2011). There is some evidence that ASICs can also play role in cancer progression. ASIC1 and ASIC2 have effects on the growth and migration of glioblastoma cells (Berdiev et al., 2003). Berdiev et al. demonstrated that in grade IV gliomas, glioma cation current is mediated by mixed ASIC1, ASIC2 and inhibition of this conductance decreases glioma growth and cell migration. It has also been shown that knockdown of ASIC1 and ENaC inhibits glioblastoma cell migration (Kapoor et al., 2009). In contrast to ASIC1, increasing surface expression of ASIC2 suppresses the proliferation and migration of GBM cells (Vila-Carriles et al., 2006).

Recently Duan et al also showed that ASIC1 gene deletion suppressed brain derived neurotrophic factor (BDNF) in mice. The BDNF/TrkB pathway enhances ASICla ion activity via the phosphoinositide 3-kinase (PI3K)-protein kinase B (PKB/Akt) cascade. PKB/Akt phosphorylates cytoplasmic Ser-25 residue of ASIC1a, resulting in increased trafficking activity and surface expression. By this they proposed a new mechanism for pain hypersensitivity (Duan et al., 2012). ASICs' activity and contribution toward bone-related pain make it a possible target for buffer therapy to neutralize metastatic acid (Nagae et al., 2007; Sluka et al., 2009). In continuation of this observation, a new trial is currently recruiting late-stage cancer patients to further test the ability of buffer therapy to reduce cancer related pain (NCT01846429: Oral Bicarbonate as Adjuvant for Pain Reduction in Patients With Tumor Related Pain, sponsored by H. Lee Moffitt Cancer Center and Research Institute).

\section{TRANSIENT RECEPTOR POTENTIAL CHANNEL VANILLOID SUBFAMILY 1 (TRPV1)}

TRPV1 channels are cation channels with a high selectivity for $\mathrm{Ca}^{2+}$. Extracellular acidity activates and opens TRPV1 channels in the absence of other stimuli. TRPV1 is not the only proton sensing protein in the family of TRPVs as it has been shown that TRPV4 is also activated by protons in the absence of extracellular $\mathrm{Ca}^{2+}$ (Holzer, 2009). TRPV1 is involved in nociception and has been particularly investigated in metastatic bone pain (Kato and Morita, 2013). It has also been reported that the acidic microenvironment of the bone cancer is responsible for the TRPV1-mediated pain. Neurons near metastatic lesions sense the high proton concentration of the tumor environment using these proton-sensing ion channels (Yoneda et al., 2011). TRPV1 is expressed and upregulated in different cancers such as human prostate cancer cells and its activation induces Akt and ERK activation suggesting that TRPV1 activation promotes prostate cancer progression. In contrast, in other reports, activation of TRPV1 leads to induction of apoptosis in cancer cells (Bode and Dong, 2009; Kalogris et al., 2010).

\section{CONCLUSIONS}

Historically, the effect of extracellular acidosis had been thought to be transduced via acidification of the $\mathrm{pH}_{\mathrm{i}}$. However, cells in general, and cancer cells in particular, have redundant and highly active proton exporting mechanisms to maintain the $\mathrm{pH}_{\mathrm{i}}$ within tight bounds (7.2-7.4) even in the presence of severe extracellular acidosis. An alternative view has emerged over the past decade that the extracellular surface of mammalian cells contains a number of acid-sensors, mediated primarily through expression of surface-accessible histidines. These receptors transduce signals to the cytoplasm and nucleus mediated by cAMP, $\mathrm{Ca}^{2+}$, and $\mathrm{K}^{+}$, to affect cellular survival, proliferation signaling and cytoskeletal remodeling. Clearly, this is an active and important area of basic research, with implications for normal physiology and pathophysiology.

It is somewhat surprising that there is little evidence for direct mechanistic connectivity between acid sensors and acid transporters. This is particularly true in cancer cells that survive and proliferate in chronically acidic conditions. Acid-sensing proteins affect intracellular signal transduction pathways and gene expression, yet surprisingly none of these appear to directly activate proton extrusion mechanisms. This might suggest that either a low $\mathrm{pH}_{\mathrm{e}}$ does not contribute greatly to the intracellular acid load or there is a connection that has not yet been elaborated. One proof for the first hypothesis would be that at a nominal membrane potential of $-58 \mathrm{mV}$, the Nernst equation predicts that the equilibrium $\mathrm{pH}_{\mathrm{i}}$ should be $1.0 \mathrm{pH}$ unit below that of $\mathrm{pH}_{\mathrm{e}}$. With a reversed $\mathrm{pH}$ gradient there is a large proton motive force driving $\mathrm{H}^{+}$into cells. However, even though the permeability of $\mathrm{H}^{+}$to lipid bilayers is orders of magnitude higher than alkali ions, it is still quite low, between $10^{-5}-10^{-7} \mathrm{~cm} \mathrm{~s}$ (Nichols and Deamer, 1980; Gutknecht, 1984) implying that the inward directed passive flux of $\mathrm{H}^{+}$across bilayers is much lower than the metabolically produced or outwardly transported flux of $\mathrm{H}^{+}$. Consequently, the effect of acidic $\mathrm{pH}_{\mathrm{e}}$ on the $\mathrm{pH}_{\mathrm{i}}$ is indirect and thus, it may not be physiologically necessary to couple $\mathrm{H}^{+}$sensing to $\mathrm{H}^{+}$extrusion. Another hypothesis would be that the effect of acidic $\mathrm{pH}_{\mathrm{e}}$ on the $\mathrm{pH}_{\mathrm{i}}$ is mediated by highly regulated and coordinated families of carriers. These are most probably electroneutral $\mathrm{HCO}_{3}^{-}$transporters since the electoneutral transporters react only to the concentration gradients and not the electromotive force. Uncovering mechanisms of $\mathrm{pH}_{\mathrm{e}}$ mediation by $\mathrm{pH}_{\mathrm{i}}$ or vice versa could be an interesting avenue of future investigation in the field of $\mathrm{pH}$ sensing and regulation in cancer.

\section{REFERENCES}

Amith, S. R. and Fliegel, L. (2013). Regulation of the Na+/H+ Exchanger (NHE1) in breast cancer metastasis. Cancer Res. 73, 1259-1264. doi: 10.1158/00085472.CAN-12-4031

Barathova, M., Takacova, M., Holotnakova, T., Gibadulinova, A., Ohradanova, A., Zatovicova, M., et al. (2008). Alternative splicing variant of the hypoxia marker carbonic anhydrase IX expressed independently of hypoxia and tumor phenotype. Br. J. Cancer 98, 129-136. doi: 10.1038/sj.bjc.6604111

Barneaud-Rocca, D., Borgese, F., and Guizouarn, H. (2011). Dual transport properties of anion exchanger 1: the same transmembrane segment is involved in anion exchange and in a cation leak. J. Biol. Chem. 286, 8909-8916. doi: 10.1074/jbc.M110.166819

Berdiev, B. K., Xia, J., Mclean, L. A., Markert, J. M., Gillespie, G. Y., Mapstone, T. B., et al. (2003). Acid-sensing ion channels in malignant gliomas. J. Biol. Chem. 278, 15023-15034. doi: 10.1074/jbc.M300991200

Bernstein, B. W., and Bamburg, J. R. (2010). ADF/cofilin: a functional node in cell biology. Trends Cell Biol. 20, 187-195. doi: 10.1016/j.tcb.2010.01.001 
Bode, A. M., and Dong, Z. (2009). Cancer prevention research—then and now. Nat. Rev. Cancer 9, 508-516. doi: 10.1038/nrc2646

Boedtkjer, E., and Aalkjaer, C. (2012). Intracellular pH in the resistance vasculature: regulation and functional implications. J. Vasc. Res. 49, 479-496. doi: $10.1159 / 000341235$

Boedtkjer, E., Damkier, H. H., and Aalkjaer, C. (2012). NHE1 knockout reduces blood pressure and arterial media/lumen ratio with no effect on resting $\mathrm{pH}_{\mathrm{i}}$ in the vascular wall. J. Physiol. 590, 1895-1906. doi: 10.1113/jphysiol.2011.227132

Boedtkjer, E., Moreira, J. M., Mele, M., Vahl, P., Wielenga, V. T., Christiansen, P. M., et al. (2013). Contribution of $\mathrm{Na}+, \mathrm{HCO} 3$-cotransport to cellular $\mathrm{pH}$ control in human breast cancer: a role for the breast cancer susceptibility locus NBCn1 (SLC4A7). Int. J. Cancer 132, 1288-1299. doi: 10.1002/ijc.27782

Bourguignon, L. Y., Singleton, P. A., Diedrich, F., Stern, R. and Gilad, E. (2004). CD44 interaction with $\mathrm{Na}+\mathrm{H}+$ exchanger (NHE1) creates acidic microenvironments leading to hyaluronidase-2 and cathepsin B activation and breast tumor cell invasion. J. Biol. Chem. 279, 26991-27007. doi: 10.1074/jbc.M311838200

Bourguignon, L. Y., Zhu, H., Shao, L., and Chen, Y. W. (2001). CD44 interaction with c-Src kinase promotes cortactin-mediated cytoskeleton function and hyaluronic acid-dependent ovarian tumor cell migration. J. Biol. Chem. 276, 7327-7336. doi: 10.1074/jbc.M006498200

Bradley, A. J., Lim, Y. Y., and Singh, F. M. (2011). Imaging features, follow-up, and management of incidentally detected renal lesions. Clin. Radiol. 66, 1129-1139. doi: 10.1016/j.crad.2011.07.044

Bravo-Cordero, J. J., Magalhaes, M. A., Eddy, R. J., Hodgson, L., and Condeelis, J. (2013). Functions of cofilin in cell locomotion and invasion. Nat. Rev. Mol. Cell Biol. 14, 405-415. doi: 10.1038/nrm3609

Busco, G., Cardone, R. A., Greco, M. R., Bellizzi, A., Colella, M., Antelmi, E., et al. (2010). NHE1 promotes invadopodial ECM proteolysis through acidification of the peri-invadopodial space. FASEB J. 24, 3903-3915. doi: 10.1096/fj.09-149518

Castellone, R. D., Leffler, N. R., Dong, L., and Yang, L. V. (2011). Inhibition of tumor cell migration and metastasis by the proton-sensing GPR4 receptor. Cancer Lett. 312, 197-208. doi: 10.1016/j.canlet.2011.08.013

Chen, H., Wang, L., Beretov, J., Hao, J., Xiao, W., and Li, Y. (2010). Co-expression of CD147/EMMPRIN with monocarboxylate transporters and multiple drug resistance proteins is associated with epithelial ovarian cancer progression. Clin. Exp. Metastasis 27, 557-569. doi: 10.1007/s10585-010-9345-9

Chiang, Y., Chou, C. Y., Hsu, K. F., Huang, Y. F., and Shen, M. R. (2008). EGF upregulates $\mathrm{Na}^{+} / \mathrm{H}^{+}$exchanger NHE1 by post-translational regulation that is important for cervical cancer cell invasiveness. J. Cell Physiol. 214, 810-819. doi: 10.1002/jcp. 21277

Cooper, G. J., Zhou, Y., Bouyer, P., Grichtchenko, Ii., and Boron, W. F. (2002). Transport of volatile solutes through AQP1. J. Physiol. 542, 17-29. doi: 10.1113/jphysiol.2002.023218

Critchley, D. R. (2009). Biochemical and structural properties of the integrinassociated cytoskeletal protein talin. Annu. Rev. Biophys. 38, 235-254. doi: 10.1146/annurev.biophys.050708.133744

Donaldson, J. G., and Jackson, C. L. (2011). ARF family G proteins and their regulators: roles in membrane transport, development and disease. Nat. Rev. Mol. Cell Biol. 12, 362-375. doi: 10.1038/nrm3117

Duan, B., Liu, D. S., Huang, Y., Zeng, W. Z., Wang, X., Yu, H., et al. (2012). PI3kinase/Akt pathway-regulated membrane insertion of acid-sensing ion channel la underlies BDNF-induced pain hypersensitivity. J. Neurosci. 32, 6351-6363. doi: 10.1523/JNEUROSCI.4479-11.2012

Enerson, B. E. and Drewes, L. R. (2003). Molecular features, regulation, and function of monocarboxylate transporters: implications for drug delivery. J. Pharm. Sci. 92, 1531-1544. doi: 10.1002/jps.10389

Frantz, C., Barreiro, G., Dominguez, L., Chen, X., Eddy, R., Condeelis, J., et al. (2008). Cofilin is a pH sensor for actin free barbed end formation: role of phosphoinositide binding. J. Cell Biol. 183, 865-879. doi: 10.1083/jcb.2008 04161

Frantz, C., Karydis, A., Nalbant, P., Hahn, K. M., and Barber, D. L. (2007). Positive feedback between $\mathrm{Cdc} 42$ activity and $\mathrm{H}^{+}$efflux by the $\mathrm{Na}-\mathrm{H}$ exchanger NHE1 for polarity of migrating cells. J. Cell Biol. 179, 403-410. doi: 10.1083/jcb.200704169

Gallagher, F. A., Kettunen, M. I., Day, S. E., Hu, D. E., Ardenkjaer-Larsen, J. H., Zandt, R., et al. (2008). Magnetic resonance imaging of $\mathrm{pH}$ in vivo using hyperpolarized 13C-labelled bicarbonate. Nature 453, 940-943. doi: 10.1038 /nature 07017
Gatenby, R. A., and Gillies, R. J. (2004). Why do cancers have high aerobic glycolysis? Nat. Rev. Cancer 4, 891-899. doi: 10.1038/nrc1478

Gatenby, R. A., and Gillies, R. J. (2008). A microenvironmental model of carcinogenesis. Nat. Rev. Cancer 8, 56-61. doi: 10.1038/nrc2255

Gatenby, R. A., Grove, O., and Gillies, R. J. (2013). Quantitative imaging in cancer evolution and ecology. Radiology 269, 8-14. doi: 10.1148/radiol.13122697

Gillies, R. J. (2002). In vivo molecular imaging. J. Cell Biochem. Suppl. 39, 231-238. doi: $10.1002 /$ jcb. 10450

Glitsch, M. (2011). Protons and Ca2+: ionic allies in tumor progression? Physiology (Bethesda) 26, 252-265. doi: 10.1152/physiol.00005.2011

Glunde, K., Foss, C. A., Takagi, T., Wildes, F., and Bhujwalla, Z. M. (2005). Synthesis of 6'-O-lissamine-rhodamine B-glucosamine as a novel probe for fluorescence imaging of lysosomes in breast tumors. Bioconjug Chem. 16, 843-851. doi: 10.1021/bc050046n

Glunde, K., Guggino, S. E., Solaiyappan, M., Pathak, A. P., Ichikawa, Y., and Bhujwalla, Z. M. (2003). Extracellular acidification alters lysosomal trafficking in human breast cancer cells. Neoplasia 5, 533-545.

Gottlieb, R. A., Nordberg, J., Skowronski, E., and Babior, B. M. (1996). Apoptosis induced in Jurkat cells by several agents is preceded by intracellular acidification. Proc. Natl. Acad. Sci. U.S.A. 93, 654-658. doi: 10.1073/pnas.93.2.654

Gutknecht, J. (1984). Proton/hydroxide conductance through lipid bilayer membranes. J. Membr. Biol. 82, 105-112. doi: 10.1007/BF01870737

Halestrap, A. P. (2012). The monocarboxylate transporter family-Structure and functional characterization. IUBMB Life 64, 1-9. doi: 10.1002/iub.573

Halestrap, A. P., and Wilson, M. C. (2012). The monocarboxylate transporter family-role and regulation. IUBMB Life 64, 109-119. doi: 10.1002/iub.572

Hanahan, D., and Weinberg, R. A. (2011). Hallmarks of cancer: the next generation. Cell 144, 646-674. doi: 10.1016/j.cell.2011.02.013

Hang, L. H., Yang, J. P., Yin, W., Wang, L. N., Guo, F., Ji, F. H., et al. (2012). Activation of spinal TDAG8 and its downstream PKA signaling pathway contribute to bone cancer pain in rats. Eur. J. Neurosci. 36, 2107-17. doi: 10.1111/j.1460-9568.2012.08087.x

Hansen, M. D., and Kwiatkowski, A. V. (2013). Control of actin dynamics by allosteric regulation of actin binding proteins. Int. Rev. Cell Mol. Biol. 303, 1-25. doi: 10.1016/B978-0-12-407697-6.00001-5

Hashim, A. I., Zhang, X., Wojtkowiak, J. W., Martinez, G. V., and Gillies, R. J. (2011). Imaging $\mathrm{pH}$ and metastasis. NMR Biomed, 24, 582-91. doi: $10.1002 / \mathrm{nbm} .1644$

He, J., Haney, R. M., Vora, M., Verkhusha, V. V., Stahelin, R. V., and Kutateladze, T. G. (2008). Molecular mechanism of membrane targeting by the GRP1 PH domain. J. Lipid Res. 49, 1807-1815. doi: 10.1194/jlr.M800150-JLR200

He, J., Scott, J. L., Heroux, A., Roy, S., Lenoir, M., Overduin, M., et al. (2011). Molecular basis of phosphatidylinositol 4-phosphate and ARF1 GTPase recognition by the FAPP1 pleckstrin homology (PH) domain. J. Biol. Chem. 286, 18650-18657. doi: 10.1074/jbc.M111.233015

Hinton, A., Sennoune, S. R., Bond, S., Fang, M., Reuveni, M., Sahagian, G. G., et al. (2009). Function of a subunit isoforms of the V-ATPase in $\mathrm{pH}$ homeostasis and in vitro invasion of MDA-MB231 human breast cancer cells. J. Biol. Chem. 284, 16400-16408. doi: 10.1074/jbc.M901201200

Holzer, P. (2009). Acid-sensitive ion channels and receptors. Handb. Exp. Pharmacol. 194, 283-332. doi: 10.1007/978-3-540-79090-7 9

Horova, V., Hradilova, N., Jelinkova, I., Koc, M., Svadlenka, J., Brazina, J., et al. (2013). Inhibition of vacuolar ATPase attenuates the TRAIL-induced activation of caspase- 8 and modulates the trafficking of TRAIL receptosomes. FEBS J. 280, 3436-3450. doi: 10.1111/febs.12347

Huang, W. C., Swietach, P., Vaughan-Jones, R. D., Ansorge, O., and Glitsch, M. D. (2008). Extracellular acidification elicits spatially and temporally distinct $\mathrm{Ca} 2+$ signals. Curr. Biol. 18, 781-785. doi: 10.1016/j.cub.2008.04.049

Huber, V., de Milito, A., Harguindey, S., Reshkin, S. J., Wahl, M. L., Rauch, C., et al. (2010). Proton dynamics in cancer. J. Transl. Med. 8, 57. doi: 10.1186/14795876-8-57

Ibrahim-Hashim, A., Cornnell, H. H., Abrahams, D., Lloyd, M., Bui, M., Gillies, R. J., and Gatenby, R. A. (2012). Systemic buffers inhibit carcinogenesis in TRAMP mice. J. Urol. 188, 624-631. doi: 10.1016/j.juro.2012.03.113

Ihara, Y., Kihara, Y., Hamano, F., Yanagida, K., Morishita, Y., Kunita, A., et al. (2010). The $G$ protein-coupled receptor T-cell death-associated gene 8 (TDAG8) facilitates tumor development by serving as an extracellular pH sensor. Proc. Natl. Acad. Sci. U.S.A. 107, 17309-17314. doi: $10.1073 /$ pnas. 1001165107 
Ilie, M., Hofman, V., Zangari, J., Chiche, J., Mouroux, J., Mazure, N. M., et al. (2013). Response of CAIX and CAXII to in vitro re-oxygenation and clinical significance of the combined expression in NSCLC patients. Lung Cancer 82, 16-23. doi: 10.1016/j.lungcan.2013.07.005

Ishii, S., Kihara, Y., and Shimizu, T. (2005). Identification of T cell death-associated gene 8 (TDAG8) as a novel acid sensing G-protein-coupled receptor. J. Biol. Chem. 280, 9083-9087. doi: 10.1074/jbc.M407832200

Jasti, J., Furukawa, H., Gonzales, E. B., and Gouaux, E. (2007). Structure of acidsensing ion channel 1 at 1.9 A resolution and low $\mathrm{pH}$. Nature 449, 316-323. doi: 10.1038 /nature06163

Kalogris, C., Caprodossi, S., Amantini, C., Lambertucci, F., Nabissi, M., Morelli, M. B., et al. (2010). Expression of transient receptor potential vanilloid-1 (TRPV1) in urothelial cancers of human bladder: relation to clinicopathological and molecular parameters. Histopathology 57, 744-752. doi: 10.1111/j.13652559.2010.03683.x

Kan, Z., Jaiswal, B. S., Stinson, J., Janakiraman, V., Bhatt, D., Stern, H. M., et al. (2010). Diverse somatic mutation patterns and pathway alterations in human cancers. Nature 466, 869-873. doi: 10.1038/nature09208

Kapoor, N., Menon, S. T., Chauhan, R., Sachdev, P., and Sakmar, T. P. (2009). Structural evidence for a sequential release mechanism for activation of heterotrimeric G proteins. J. Mol. Biol. 393, 882-897. doi: 10.1016/j.jmb.2009.08.043

Kato, K., and Morita, I. (2013). Promotion of osteoclast differentiation and activation in spite of impeded osteoblast-lineage differentiation under acidosis: effects of acidosis on bone metabolism. Biosci. Trends 7, 33-41. doi: 10.5582/bst.2013.v7.1.33

Koukourakis, M. I., Giatromanolaki, A., Harris, A. L., and Sivridis, E. (2006). Comparison of metabolic pathways between cancer cells and stromal cells in colorectal carcinomas: a metabolic survival role for tumor-associated stroma. Cancer Res. 66, 632-637. doi: 10.1158/0008-5472.CAN-05-3260

Lagadic-Gossmann, D., Huc, L., and Lecureur, V. (2004). Alterations of intracellular pH homeostasis in apoptosis: origins and roles. Cell Death Differ. 11, 953-961. doi: 10.1038/sj.cdd.4401466

Leanza, L., Biasutto, L., Manago, A., Gulbins, E., Zoratti, M., and Szabo, I. (2013). Intracellular ion channels and cancer. Front. Physiol. 4:227. doi: 10.3389/fphys.2013.00227

Lee, S. A., Eyeson, R., Cheever, M. L., Geng, J., Verkhusha, V. V., Burd, C., et al. (2005). Targeting of the FYVE domain to endosomal membranes is regulated by a histidine switch. Proc. Natl. Acad. Sci. U.S.A. 102, 13052-7. doi: 10.1073/pnas.0503900102

Lee, W. Y., Huang, S. C., Hsu, K. F., Tzeng, C. C., and Shen, W. L. (2008). Roles for hypoxia-regulated genes during cervical carcinogenesis: somatic evolution during the hypoxia-glycolysis-acidosis sequence. Gynecol. Oncol. 108, 377-384. doi: 10.1016/j.ygyno.2007.10.034

Li, J., Guo, B., Wang, J., Cheng, X., Xu, Y., and Sang, J. (2013). Ovarian cancer G protein coupled receptor 1 suppresses cell migration of MCF7 breast cancer cells via a Galpha12/13-Rho-Racl pathway. J. Mol. Signal. 8, 6. doi: 10.1186/17502187-8-6

Lin, Y., Chang, G., Wang, J., Jin, W., Wang, L., Li, H., et al. (2011a). NHE1 mediates MDA-MB-231 cells invasion through the regulation of MT1-MMP. Exp. Cell Res. 317, 2031-2040. doi: 10.1016/j.yexcr.2011.05.026

Lin, Y., Wang, J., Jin, W., Wang, L., Li, H., Ma, L., et al. (2011b). NHE1 mediates migration and invasion of $\mathrm{HeLa}$ cells via regulating the expression and localization of MT1-MMP. Cell Biochem. Funct. doi: 10.1002/ cbf.1815. [Epub ahead of print].

Liu, J. P., Nakakura, T., Tomura, H., Tobo, M., Mogi, C., Wang, J. Q., et al. (2010). Each one of certain histidine residues in G-protein-coupled receptor GPR4 is critical for extracellular proton-induced stimulation of multiple G-protein-signaling pathways. Pharmacol. Res. 61, 499-505. doi: 10.1016/j.phrs.2010.02.013

Lope-Piedrafita, S., Garcia-Martin, M. L., Galons, J. P., Gillies, R. J., and Trouard, T. P. (2008). Longitudinal diffusion tensor imaging in a rat brain glioma model. NMR Biomed. 21, 799-808. doi: 10.1002/nbm.1256

Ludwig, F. T., Schwab, A., and Stock, C. (2013). The Na+/H+-exchanger (NHE1) generates $\mathrm{pH}$ nanodomains at focal adhesions. J. Cell Physiol. 228, 1351-1358. doi: $10.1002 /$ jcp. 24293

Ludwig, M. G., Vanek, M., Guerini, D., Gasser, J. A., Jones, C. E., Junker, U., et al. (2003). Proton-sensing G-protein-coupled receptors. Nature 425, 93-98. doi: 10.1038 /nature01905
Magalhaes, M. A., Larson, D. R., Mader, C. C., Bravo-Cordero, J. J., GilHenn, H., Oser, M., et al. (2011). Cortactin phosphorylation regulates cell invasion through a pH-dependent pathway. J. Cell Biol. 195, 903-920. doi: 10.1083/jcb.201103045

Martin, C., Pedersen, S. F., Schwab, A., and Stock, C. (2011). Intracellular pH gradients in migrating cells. Am. J. Physiol. Cell Physiol. 300, C490-C495. doi: 10.1152/ajpcell.00280.2010

Martinez-Zaguilan, R., Raghunand, N., Lynch, R. M., Bellamy, W., Martinez, G. M., Rojas, B., et al. (1999). pH and drug resistance. I. Functional expression of plasmalemmal V-type H+-ATPase in drug-resistant human breast carcinoma cell lines. Biochem. Pharmacol. 57, 1037-1046. doi: 10.1016/S0006-2952(99)00022-2

Martinez-Zaguilan, R., Tompkins, L. S., Gillies, R. J., and Lynch, R. M. (2013). Simultaneous analysis of intracellular $\mathrm{pH}$ and $\mathrm{Ca}^{2+}$ from cell populations. Methods Mol. Biol. 937, 253-271. doi: 10.1007/978-1-62703-086-1_16

Matsuyama, S., and Reed, J. C. (2000). Mitochondria-dependent apoptosis and cellular $\mathrm{pH}$ regulation. Cell Death Differ. 7, 1155-1165. doi: 10.1038/sj.cdd.4400779

McIntyre, A., Patiar, S., Wigfield, S., Li, J. L., Ledaki, I., Turley, H., et al. (2012). Carbonic anhydrase IX promotes tumor growth and necrosis in vivo and inhibition enhances anti-VEGF therapy. Clin. Cancer Res. 18, 3100-3111. doi: 10.1158/1078-0432.CCR-11-1877

Moolenaar, W. H., Defize, L. H., and de Laat, S. W. (1986). Ionic signalling by growth factor receptors. J. Exp. Biol. 124, 359-373.

Morris, M. E., and Felmlee, M. A. (2008). Overview of the proton-coupled MCT (SLC16A) family of transporters: characterization, function and role in the transport of the drug of abuse gamma-hydroxybutyric acid. AAPS J. 10, 311-321. doi: 10.1208/s12248-008-9035-6

Nagae, M., Hiraga, T., and Yoneda, T. (2007). Acidic microenvironment created by osteoclasts causes bone pain associated with tumor colonization. J. Bone Miner. Metab. 25, 99-104. doi: 10.1007/s00774-006-0734-8

Nakajima, E. C., and Van Houten, B. (2013). Metabolic symbiosis in cancer: refocusing the Warburg lens. Mol. Carcinog. 52, 329-37. doi: 10.1002/mc.21863

Nichols, J. W., and Deamer, D. W. (1980). Net proton-hydroxyl permeability of large unilamellar liposomes measured by an acid-base titration technique. Proc. Natl. Acad. Sci. U.S.A. 77, 2038-2042. doi: 10.1073/pnas.77.4.2038

Perez-Sayans, M., Garcia-Garcia, A., Reboiras-Lopez, M. D., and Gandara-Vila, P. (2009a). Role of V-ATPases in solid tumors: importance of the subunit C (Review). Int. J. Oncol. 34, 1513-1520. doi: 10.3892/ijo_00000280

Perez-Sayans, M., Somoza-Martin, J. M., Barros-Angueira, F., Rey, J. M., and Garcia-Garcia, A. (2009b). V-ATPase inhibitors and implication in cancer treatment. Cancer Treat Rev. 35, 707-713. doi: 10.1016/j.ctrv.2009.08.003

Pignataro, G., Cuomo, O., Esposito, E., Sirabella, R., di Renzo, G., and Annunziato, L. (2011). ASICla contributes to neuroprotection elicited by ischemic preconditioning and postconditioning. Int. J. Physiol. Pathophysiol. Pharmacol. $3,1-8$.

Pinheiro, C., Albergaria, A., Paredes, J., Sousa, B., Dufloth, R., Vieira, D., et al (2010). Monocarboxylate transporter 1 is up-regulated in basal-like breast carcinoma. Histopathology 56, 860-867. doi: 10.1111/j.1365-2559.2010. 03560.x

Pinheiro, C., Longatto-Filho, A., Pereira, S. M., Etlinger, D., Moreira, M. A., Jube, L. F., et al. (2009a). Monocarboxylate transporters 1 and 4 are associated with CD147 in cervical carcinoma. Dis. Markers 26, 97-103. doi: $10.1155 / 2009 / 169678$

Pinheiro, C., Longatto-Filho, A., Simoes, K., Jacob, C. E., Bresciani, C. J. Zilberstein, B., et al. (2009b). The prognostic value of CD147/EMMPRIN is associated with monocarboxylate transporter 1 co-expression in gastric cancer. Eur. J. Cancer 45, 2418-2424. doi: 10.1016/j.ejca.2009.06.018

Pouyssegur, J., Dayan, F., and Mazure, N. M. (2006). Hypoxia signalling in cancer and approaches to enforce tumor regression. Nature 441, 437-443. doi: 10.1038 /nature04871

Pouyssegur, J., and Mechta-Grigoriou, F. (2006). Redox regulation of the hypoxiainducible factor. Biol. Chem. 387, 1337-1346. doi: 10.1515/BC.2006.167

Radu, C. G., Nijagal, A., Mclaughlin, J., Wang, L., and Witte, O. N. (2005). Differential proton sensitivity of related $G$ protein-coupled receptors $T$ cell death-associated gene 8 and G2A expressed in immune cells. Proc. Natl. Acad. Sci. U.S.A. 102, 1632-1637. doi: 10.1073/pnas.0409415102

Raghunand, N., Altbach, M. I., van Sluis, R., Baggett, B., Taylor, C. W., Bhujwalla, Z. M., et al. (1999). Plasmalemmal pH-gradients in drug-sensitive and drugresistant MCF-7 human breast carcinoma xenografts measured by $31 \mathrm{P}$ magnetic 
resonance spectroscopy. Biochem. Pharmacol. 57, 309-312. doi: 10.1016/S00062952(98)00306-2

Robey, I. F., Baggett. B. K., Kirkpatrick, N. D., Roe, D. J., Dosescu, J., Sloane, B. F., et al. (2009). Bicarbonate increases tumor $\mathrm{pH}$ and inhibits spontaneous metastases. Cancer Res. 69, 2260-2268. doi: 10.1158/0008-5472.CAN-07-5575

Saw, N. M., Kang, S. Y., Parsaud, L., Han, G. A., Jiang, T., Grzegorczyk, K., et al. (2011). Vacuolar (H+)-ATPase subunits Voal and Voa2 cooperatively regulate secretory vesicle acidification, transmitter uptake, and storage. Mol. Biol. Cell 22, 3394-3409. doi: 10.1091/mbc.E11-02-0155

Schonichen, A., Mannherz, H. G., Behrmann, E., Mazur, A. J., Kuhn, S., Silvan, U., et al. (2013a). FHOD1 is a combined actin filament capping and bundling factor that selectively associates with actin arcs and stress fibers. J. Cell Sci. 126, 1891-1901. doi: 10.1242/jcs.126706

Schonichen, A., Webb, B. A., Jacobson, M. P., and Barber, D. L. (2013b). Considering protonation as a posttranslational modification regulating protein structure and function. Annu. Rev. Biophys. 42, 289-314. doi: 10.1146/annurevbiophys-050511-102349

Schornack, P. A., and Gillies, R. J. (2003). Contributions of cell metabolism and $\mathrm{H}^{+}$ diffusion to the acidic $\mathrm{pH}$ of tumor. Neoplasia 5, 135-145.

Sherwood, T. W., and Askwith, C. C. (2008). Endogenous arginine-phenylalanineamide-related peptides alter steady-state desensitization of ASICla. J. Biol. Chem. 283, 1818-1830. doi: 10.1074/jbc.M705118200

Sherwood, T. W., Frey, E. N., and Askwith, C. C. (2012). Structure and activity of the acid-sensing ion channels. Am. J. Physiol. Cell Physiol. 303, C699-C710. doi: 10.1152/ajpcell.00188.2012

Sidani, M., Wessels, D., Mouneimne, G., Ghosh, M., Goswami, S., Sarmiento, C., et al. (2007). Cofilin determines the migration behavior and turning frequency of metastatic cancer cells. J. Cell Biol. 179, 777-791. doi: 10.1083/jcb.200707009

Sin, W. C., Zhang, Y., Zhong, W., Adhikarakunnathu, S., Powers, S., Hoey, T., et al. (2004). G protein-coupled receptors GPR4 and TDAG8 are oncogenic and overexpressed in human cancers. Oncogene 23, 6299-6303. doi: 10.1038/sj.onc. 1207838

Singh, L. S., Berk, M., Oates, R., Zhao, Z., Tan, H., Jiang, Y., et al. (2007). Ovarian cancer G protein-coupled receptor 1, a new metastasis suppressor gene in prostate cancer. J. Natl. Cancer Inst. 99, 1313-1327. doi: 10.1093/jnci/djm107

Sluka, K. A., Winter, O. C., and Wemmie, J. A. (2009). Acid-sensing ion channels: a new target for pain and CNS diseases. Curr. Opin. Drug Discov. Devel. 12, 693-704.

Sonveaux, P., Vegran, F., Schroeder, T., Wergin, M. C., Verrax, J., Rabbani, Z. N., et al. (2008). Targeting lactate-fueled respiration selectively kills hypoxic tumor cells in mice. J. Clin. Invest. 118, 3930-3942. doi: 10.1172/JCI36843

Srivastava, J., Barreiro, G., Groscurth, S., Gingras, A. R., Goult, B. T., Critchley, D. R., et al. (2008). Structural model and functional significance of $\mathrm{pH}$-dependent talin-actin binding for focal adhesion remodeling. Proc. Natl. Acad. Sci. U.S.A. 105, 14436-14441. doi: 10.1073/pnas.0805163105

Steffan, J. J., Snider, J. L., Skalli, O., Welbourne, T., and Cardelli, J. A. (2009). $\mathrm{Na}^{+} / \mathrm{H}^{+}$exchangers and RhoA regulate acidic extracellular $\mathrm{pH}-$ induced lysosome trafficking in prostate cancer cells. Traffic 10, 737-753. doi: 10.1111/j.1600-0854.2009.00904.x

Stock, C., and Schwab, A. (2009). Protons make tumor cells move like clockwork. Pflugers Arch. 458, 981-92. doi: 10.1007/s00424-009-0677-8

Stubbs, M., Rodrigues, L., Howe, F. A., Wang, J., Jeong, K. S., Veech, R. L., et al. (1994). Metabolic consequences of a reversed $\mathrm{pH}$ gradient in rat tumors. Cancer Res. 54, 4011-4016.

Supuran, C. T., di Fiore, A., Alterio, V., Monti, S. M., and de Simone, G. (2010). Recent advances in structural studies of the carbonic anhydrase family: the crystal structure of human CA IX and CA XIII. Curr. Pharm. Des. 16, 3246-3254. doi: 10.2174/138161210793429841

Swietach, P., Hulikova, A., Vaughan-Jones, R. D., and Harris, A. L. (2010). New insights into the physiological role of carbonic anhydrase IX in tumor $\mathrm{pH}$ regulation. Oncogene 29, 6509-6521. doi: 10.1038/onc.2010.455
Tafreshi, N. K., Bui, M. M., Bishop, K., Lloyd, M. C., Enkemann, S. A., Lopez, A. S., et al. (2012). Non-invasive detection of breast cancer lymph node metastasis using carbonic anhydrases IX and XII targeted imaging probes. Clin. Cancer Res. 18, 207-219. doi: 10.1158/1078-0432.CCR-11-0238

Tomura, H., Mogi, C., Sato, K., and Okajima, F. (2010). [Proton-sensing G-proteincoupled receptors and their physiological roles]. Nihon Yakurigaku Zasshi 135, 240-244. doi: 10.1254/fpj.135.240

Vila-Carriles, W. H., Kovacs, G. G., Jovov, B., Zhou, Z. H., Pahwa, A. K., Colby, G., et al. (2006). Surface expression of ASIC2 inhibits the amiloride-sensitive current and migration of glioma cells. J. Biol. Chem. 281, 19220-19232. doi: 10.1074/jbc.M603100200

Vilas, G. L., Johnson, D. E., Freund, P., and Casey, J. R. (2009). Characterization of an epilepsy-associated variant of the human $\mathrm{Cl}^{-} / \mathrm{HCO}_{3}^{-}$exchanger AE3. Am. J. Physiol. Cell Physiol. 297, C526-C536. doi: 10.1152/ajpcell.00572.2008

Webb, B. A., Chimenti, M., Jacobson, M. P., and Barber, D. L. (2011). Dysregulated pH: a perfect storm for cancer progression. Nat. Rev. Cancer 11, 671-677. doi: $10.1038 / \mathrm{nrc} 3110$

Wemmie, J. A., Taugher, R. J., and Kreple, C. J. (2013). Acid-sensing ion channels in pain and disease. Nat. Rev. Neurosci. 14, 461-471. doi: 10.1038/nrn3529

Witkiewicz, A. K., Whitaker-Menezes, D., Dasgupta, A., Philp, N.J., Lin. Z., Gandara, R., et al. (2012). Using the reverse Warburg effect to identify highrisk breast cancer patients: stromal MCT4 predicts poor clinical outcome in triple-negative breast cancers. Cell Cycle 11, 1108-1117. doi: 10.4161/cc.11.6. 19530

Wyder, L., Suply, T., Ricoux, B., Billy, E., Schnell, C., Baumgarten, B. U., et al. (2011). Reduced pathological angiogenesis and tumor growth in mice lacking GPR4, a proton sensing receptor. Angiogenesis 14, 533-544. doi: 10.1007/s10456-011-9238-9

Xie, Y. F., Cai, X. L., Liu, W. L., and Deng, W. (2009). Effects of perchlorate on growth and chlorophyll fluorescence parameters of Alternanthera philoxeroides. Huan Jing Ke Xue 30, 2425-2431.

Yan, L., Chang, Z., Liu, Y., He, B. R. and Hao, D. J. (2012a). Primary spinal melanoma: a case report and literature review. Chin. Med. J. (Engl). 125, 4138-4141.

Yan, L., Singh, L. S., Zhang, L., and Xu, Y. (2012b). Role of OGR1 in myeloidderived cells in prostate cancer. Oncogene. doi: 10.1038/onc.2012.566. [Epub ahead of print].

Yoneda, T., Hata, K., Nakanishi, M., Nagae, M., Nagayama, T., Wakabayashi, H., et al. (2011). Involvement of acidic microenvironment in the pathophysiology of cancer-associated bone pain. Bone 48, 100-105. doi: 10.1016/j.bone.2010.07.009

Yuan, F. L., Wang, H. R., Yuan, W., Zhao, M. D., Cao, L., Duan, P. G., et al. (2013). Ovarian cancer $G$ protein-coupled receptor 1 is involved in acid-induced apoptosis of endplate chondrocytes in intervertebral discs. J. Bone Miner. Res. doi: 10.1002/jbmr.2030. [Epub ahead of print].

Conflict of Interest Statement: The authors declare that the research was conducted in the absence of any commercial or financial relationships that could be construed as a potential conflict of interest.

Received: 05 October 2013; paper pending published: 18 October 2013; accepted: 26 November 2013; published online: 17 December 2013.

Citation: Damaghi M, Wojtkowiak JW and Gillies RJ (2013) pH sensing and regulation in cancer. Front. Physiol. 4:370. doi: 10.3389/fphys.2013.00370

This article was submitted to Membrane Physiology and Membrane Biophysics, a section of the journal Frontiers in Physiology.

Copyright (c) 2013 Damaghi, Wojtkowiak and Gillies. This is an open-access article distributed under the terms of the Creative Commons Attribution License (CC BY). The use, distribution or reproduction in other forums is permitted, provided the original author(s) or licensor are credited and that the original publication in this journal is cited, in accordance with accepted academic practice. No use, distribution or reproduction is permitted which does not comply with these terms. 